\title{
Effects of Regulated Water Flows on Regen- eration of Fremont Cottonwood
}

\author{
PATTIE FENNER, WARD W. BRADY, AND DAVID R. PATTON
}

\section{Abstract}

The reduction in extent of riparian forests in the southwestern United States has been a topic of recent concern. The effect of dams on downstream river flow and the consequent modification of the riparian habitat was studied along the lower Salt River in central Arizona. Dams were found to change the magnitude of river flows and change the seasonal timing of flows in such a way that the habitat appeared less adapted for regeneration of Populus fremontii. Modification of river flow patterns, therefore, appears likely to have been a significant factor causing change in vegetation along the Salt River.

Riparian forests in the southwestern United States have been reduced in extent in recent history (Johnson and Jones 1977). These habitats provide food and cover for many wildlife species and shade and forage for livestock because of the relatively wet conditions in an otherwise arid to semiarid environment.

This study investigated the effects of releasing water from dams on the establishment of riparian vegetation. The hypothesis examined was that dams modify local conditions to the extent that some plant species find the riparian zone less favorable or even unfavorable as habitat.

Of particular interest was the effect of dams on patterns of seasonal flooding and how this influences seedling establishment. Seasonal flooding is an important factor in Fremont cottonwood (Populus fremontii) regeneration because of the tree's short seed viability. ${ }^{1}$ Research on the effects of dams on riverbed morphology also has been conducted (Priest and Shindala 1969a, 1969b, and 1969c; Black 1973; Blench 1972); however, few studies related changes in riverbed morphology to subsequent vegetative changes (Warren and Turner 1975, Turner and Karpiscak 1980).

\section{Study Area}

The lower Salt River in central Arizona is a 80-km-long dam and reservoir system designed to provide water and hydroelectric power to the greater Phoenix metropolitan area. Dams along the river and the dates of their completion are: Roosevelt (1911) (furthest upstream); Mormon Flat (1925); Horse Mesa (1927); and Stewart Mountain (1930) (furthest downstream). Granite Reef Diversion Dam is a low irrigation diversion structure constructed in 1903 and is approximatcly $15 \mathrm{~km}$ downstream from Stewart Mountain Dam. This structure is not considered a dam in the context of this study, because it does not create a reservoir. The Verde River flows into the Salt River immediately above the Granite Reef structure.

The area selected for this study was the Blue Point Cottonwoods, a proposed Forest Service Scientific/Education Natural Area located between Stewart Mountain Dam and Granite Reef

Authors are range conservationist, USDA Forest Service, Tonto National Forest, 102 South 28th Street Phoenix, Ariz. 85038; and associate professor, Division of Agriculture, Arizona State University, Tempe 85287; and principal wildlife biologist, USDA Forest Service, Rocky Mountain Forest and Range Experiment Station, Tempe, Ariz. 85287.

'Brady, Ward W., and Pattie Fenner. 1980. Some laboratory studies of seed and seedlings of Populus fremontii Wats. Progress reported submitted to Rocky Mt. Forest and Range Exp. Sta., Tempe. Ariz.
Dam. ${ }^{2}$ The Blue Point Cottonwoods are on a secondary channel which is a relic of the main river channel. The existing Populus fremontii (Fremont cottonwood) gallery forest is decadent and has a distinctly bimodal age class distribution. Only large, decadent trees and very young individuals were found-indicating that seedling survival has been low to nonexistent for extended periods.

\section{Historical Records of Vegetation on the Salt River}

Based upon the available historical records (Bandelier 1892, Marion 1965, Thwaites 1905) and the current decadent state of the vegetation, it appears that the Blue Point Cottonwood area, and in general, the entire riparian ecosystem of the lower Salt River has substantially changed in the past 100 to 150 years.

Changes in the Salt River system have been attributed primarily to these 3 activities:

Grazing.-Many cattle were brought into Arizona in the late 1800 's to early 1900's (Bryan 1928, Hastings and Turner 1972). Livestock may affect the riparian habitat either by eating and trampling seedling riparian species or by denuding the upstream watershed, leading to changes in the surface hydrology.

Groundwater Pumping.-Drawdown of ground water, especially at critical growth periods for cottonwoods, may have stunted and killed mature trees ${ }^{3}$ (Johnson et al. 1976). Declines in the water table, for example, have been observed along the Verde River Infiltration Gallery and Well Facility during periods of low river flow. ${ }^{3}$ As a result, mature cottonwood trees growing away from the main channel may not be able to reach the lower levels of groundwater. Seedlings also could be affected if the new groundwater levels are deep enough to prevent roots of the young plants from reaching a permanent water supply before the summer draught.

Dam and Reservoir Systems. - Hey (1975), Priest and Shindala (1969a, 1969b, and 1969c), and Patten ${ }^{4}$ discussed the effects of large dams on downstream riverbed morphology. These effects can be briefly summarized as erosion of the streambed resulting in channelization and an increase in the average size of the bed sediment. Also, silt bar formation is reduced relative to that observed in free-flowing rivers. The result of these changes in morphology is the production of a less favorable substrate for the establishment of cottonwoods.

\section{River Flow with Dams and Expected Flow without Dams}

Actual flows from Stewart Mountain Dam were obtained for the period October 1934 to September 1979. Estimates were made of expected flows along the same portion of the river which would have occurred had no dams been in place on the Salt River system. These expected flows were calculated using data from gauges upstream from the system of dams (i.e., upstream from Roosevelt Dam). Data collected by U.S. Geological Survey from gauges on

${ }^{2}$ Nickles, Harry R. 1978. Environmental assessment report: Blue Point cottonwood riparian restoration enclosure. Mesa Ranger District, Jonto Nat. Forest, Reg. 3, Mesa, Ariz.

${ }^{3}$ Anderson, Arthur W. 1980. Draft report on water needs of riparian vegetation along Fort McDowell Reach of the Verde River. U.S. Dep. Interior, Fish and Wildlife Serv. Albuquerque, N.M.

4Patten, D. I. 1972. Present vegetation-environmental conditions at the Orme, Buttes, Charleston and Hooker Dam locations. Bureau of Relcamation, Region 3, Boulder City, Nev. 
the Salt River and its main tributary, Tonto Creek, exists for 45 years and is continuous, except for 3 periods of flooding (7-20 February and 14-20 March 1937; and 1 October-20 December 1940) when gauges were not read on Tonto Creek (U.S. Department of Interior 1934-1979). During periods of nonflood river flow, Tonto Creek is the only measurable tributary to the Salt River (above the study area). Thus, the flow of Tonto Creek plus the flow of the Salt River before it is joined by Tonto Creek constitutes the major part of the flow that will reach the area where Stewart Mountain Dam is situated (U.S. Department of Interior 1934-1979). It must be noted that during times of large runoff from the watershed significant amounts of water enter the Salt River from ungauged sources; however, for this study it was assumed that knowledge of gauged water flow was adequate.

Maximum daily flows observed below Stewart Mountain Dam and those predicted for the same area under the hypothesis of no dams on the Salt River were summarized in frequency tables having the following categories: (1) flows less than 5.67 cubic meters/second (c.m.s.)-probably too low to sustain a mature riparian community (McNatt et al. 1980); (2) 5.67-28.32 c.m.s.low flows; (3) 28.35-141.58 c.m.s.-moderate flows which fill the channel; (4) 141.61-283.17 c.m.s.-flows which begin to overflow the channel; (5) 283.20-424.75 c.m.s. - high flows which inundate some flood plain (including the Blue Point Cottonwoods); and (6) flows greater than $424.75 \mathrm{c} . \mathrm{m}$.s. - flows which inundate large areas of flood plain. Estimates of flows necessary to overflow the channel and begin inundation of the flood plain were made using Manning's formula (Hudson 1971). These values are approximations because of the high variability in channel characteristics; however, they are consistent with observations on the study area during actual flooding.

Data collected by the U.S. Geological Survey represents average daily flows. The maximum flow for each day is not recorded; however, it can be estimated from regression equations. For each water year, 2 or more daily maximum flows are recorded, one of which is the day with the maximum flow for that year. These daily maximum flows can then be expressed as a function of average daily flow using a regression equation. This equation then can be used to find a maximum flow corresponding with each daily average flow.

A problem with this approach for predicting daily maximum flow is that, in central Arizona, the character of storms varies from season to season. Summer storms are usually sudden, produce intense precipitation, and are quickly over. They are also localized, perhaps producing torrential rains in one area and little or no rain in another area that may be only $1 \mathrm{~km}$ away. Average river flow data collected from gauges during these storms would be expected to show little correlation between maximum flows and average flows. In other words, predictability of maximum flow of a summer storm from average flow during the storm is low.

Winter storms, in contrast, are widespread, gentle rains, often lasting for days. Maximum flows are expected to be predictable and not greatly different from average flows. During the months of snowmelt, input to the river system is even steadier than during winter storms. Maximum flows should be easily predicted from averages. Thus, there are three basic "river-flow seasons"-winter, with storms usually occurring in October through February; snowmelt in March and April; and summer inflow from May to September. Regression equations were calculated for each of these seasons (Table 1). A total of 47 data pairs were available for the winter regression, 39 for the snowmelt regression, and 44 for the summer regression.

Using the 3 equations, it was possible to compute maximum daily flow for any day of the year, as long as the average daily flow was at least as large as the base for the gauge on the Salt River (113.27 c.m.s.) or, in the case of summer flows (which seldom reached $113.27 \mathrm{c.m} . \mathrm{s}$.), large enough so that extrapolation from the regression equation did not occur. For cases in which average daily
Table 1. Regression equations for the three runoff seasons, with maximum daily flow as the dependent variable and average daily flow as the independent variable.

\begin{tabular}{llccr}
\hline \hline Season & Month & Regression & R & \multicolumn{1}{c}{ SE } \\
\hline Snowmelt Mar.-Apr & Y $=-108.99+0.054 X$ & .9814 & 68.75 \\
Summer May-Sept. & Y $=88.49+0.038 X$ & .5964 & 114.22 \\
Winter & Oct-Feb. & Y $=-53.44+0.053 X$ & .8468 & 289.93 \\
\hline
\end{tabular}

flows were too low to calculate a maximum, maximum flow was set equal to the average daily flow.

\section{Dates of Seed Dispersal}

Fremont cottonwood seeds are extremely small (approximately $1 \mathrm{~mm}$ in length) and fragile, and are blown through the air with the aid of a tuft of trichomes that are outgrowths of the funiculus and placenta (Fann and Werker 1972). This dispersal occurs in the spring. Weekly counts of seeds collected in seed traps was made in an attempt to provide some quantification as to the duration and timing of seed fall. The seed trap consisted of a 7.6 liter bucket, 20 $\mathrm{cm}$ in diameter, containing water to a depth of approximately 10 $\mathrm{cm}$ (Warren and Turner 1975). This level of water was held constant by a canteen of water which was suspended nearby and connected by plastic tubing. Large objects and animals were kept out by a cover of poultry netting. Traps were checked, cleaned, and refilled with water weekly. Because viable seed normally germinate within 24 to 48 hours, ' seed counts were obtained by counting only seeds that had germinated in the trap. Three of these traps were each placed within $90 \mathrm{~m}$ of a mature Fremont cottonwood in the study area.

\section{Results and Discussion}

The pattern of river flow observed on the dammed Salt River system shows highest flows during the summer, when water is used for irrigation on farms in the Phoenix area (Table 2). Winter water release is low, unless winter storms cause a buildup in the reservoirs, in which case water is released and flows in the Salt River bed through Phoenix. Snowmelt in March signals the main season of water release, building up to an average summertime flow of 36.81 c.m.s., which generally lasts until the river water release ceases in September or October. Flows above 141.58 c.m.s. level occur infrequently, consistent with the irrigation management objectives of the dams on the Salt River.

The pattern of river flow expected were no dams present on the Salt River is substantially different than that observed with dams (Table 3). Peak water flows begin in March both with and without dams. Peak flows without dams occur during the late winter-early spring period (March-May). Dams, therefore, reduce the intensity of flow during this time and shift the period of highest weekly average flow to late spring and early summer. A comparison of patterns of flow in Tables 2 and 3 shows that dams have substantially altered timing of water flow downstream from Stewart Mountain Dam. A comparison of mean weekly flow observed below Stewart Mountain Dam with the mean weekly flow predicted had no dams been present also illustrates the effect of dams on timing of river flow (Fig. 1). In addition, dams reduce the magnitude of high flows and equalize the flow over the year (Tables 2 and 3). The effect of dams, therefore, is to reduce the incidence and magnitude of floods which would inundate the floodplain.

For example, flows exceeding approximately 280 c.m.s. are sufficient to begin inundation of the Blue Point Cottonwood area while flows exceeding approximately $425 \mathrm{c} . \mathrm{m}$.s. cause extensive inundation. Flow below Stewart Mountain dam fell in the 283.20 to 424.75 c.m.s. class a total of 21 times over the period 1934- 1979. Flows exceeded 424.75 c.m.s. 20 times in this same period. However, had dams not been present, it was predicted that flows would 


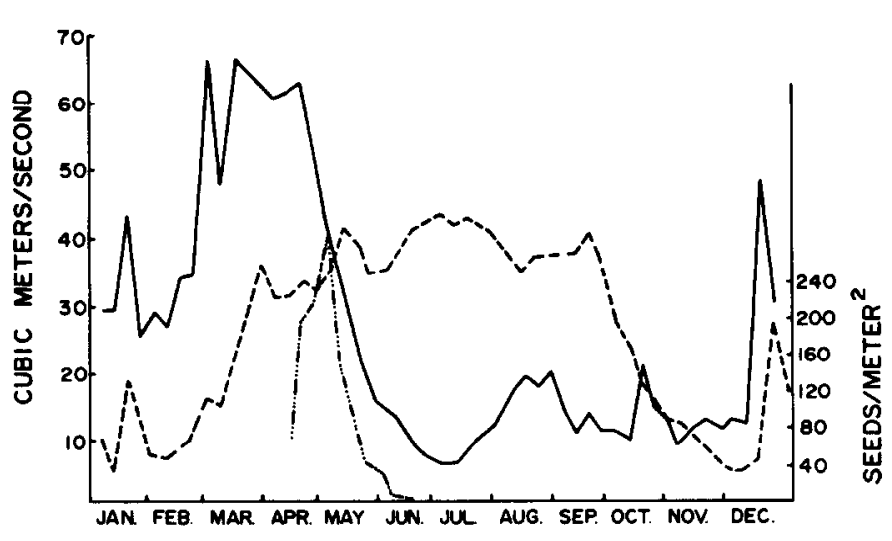

Fig. 1. Mean weekly river flow observed below Stewart Mountain Dam (--) and mean riverflows predicted had no dams been present. Data represent the period 1934 to 1979 . The approximate seedfall period for Populus fremonti (Fremont cottonwood) is also shown (--...--...)

have been in the 283.20 to 424.75 c.m.s. category 120 times and the greater than 424.75 c.m.s. category 138 times.

\section{Relationships Between River Flow in the Absence of Dams and Seed Dispersal}

Flows, in the absence of dams, large enough to cause flooding occur during winter and spring. Beginning about the middle of May, water levels decline through the summer, except for brief rises caused by summer storms. Seed dispersal occurs in the spring during the period of high flows, and by the time flows begin to recede, most Fremont cottonwood seeds have been dispersed.

For example, seed dispersal in 1980 began in mid-April, peaked in mid-May, and was complete by mid-June (Fig. 1). The close correspondence of timing of seed ripening with high river flow illustrates the adaptation of Fremont cottonwood to the environment found along the Salt River. Receding high flows leave a moist, freshly deposited alluvial substrate, which provides a favorable habitat for regeneration of Fremont cottonwood.s Further-

SBrady, Ward W., and Jay Paxon. 1980. Temporal and spatial relationships in the development of southwestern riparian gallery forests. Prog. Rep. submitted to Rocky Mt. Forest and Range Exp. Sta., Tempe, Ariz. more, cottonwood seeds germinate rapidly given a moist soil and lose viability after approximately 3 weeks. 1 Therefore, it is important that an appropriate environment be available at the time of or soon after seed dispersal.

\section{Conclusions}

The presence of dams on the Salt River has substantially changed the habitat in ways unfavorable to Fremont cottonwood regeneration. In particular, the timing and volume of water flow through the riparian community changed. The flows expected in the absence of dams would be of higher volume, reduced duration, and earlier in the season than would flows observed with dams in place. This results in less floodplain inundation. Furthermore, instead of decreasing river flow through the spring and summer, releases are maintained at a fairly regular 33.98 to 42.48 c.f.s. until fall, when Fremont cottonwoods enter dormancy. Thus, under the regulated flow regime, a large winter/spring flood does not normally occur. No alluvial seedbeds are created, partly because of lack of suspended sediment flowing down the channel, and partly because of the much smaller magnitude of river flow, which is usually confined to the channel. In addition, water levels do not gradually recede to leave a moist substrate for seed germination. Waters may recede periodically only to repeatedly inundate germinating seeds.

Modification of river flow patterns, therefore, appears likely to have significantly changed vegetation along the Salt River. The importance of this factor relative to other factors, such as grazing and pumping of groundwater, is unknown.

\section{Literature Cited}

Bandelier, A.F. 1892. (Reprint, 1976). Final report of investigations among the Indians of the southwestern United States, carried on mainly in the years from 1880 to 1885. Part II. John Wilson and Son, Univ. Press, Cambridge, Mass.

Black, Peter E. 1973. Impact of traditional water resources technology on human environment. p. 253-263. In: Water for the human environment. Vol. III: Technical Session. Proc. First World Congress on Water Resources, [Sept. 24-28, 1973, Chicago, Ill.],

Blench, T. 1972. Morphometric changes. p. 287-308. In: R.T. Oglesby, C.A. Carlson, J.A. McCann, eds. River ecology and man. Proc. Internat. Symp. on River Ecology and the Impact of Man. (Amherst, Mass. June 20-23, 1971]. Univ. of Massachusetts, Amherst.

Table 2. Frequency table showing the number of days in each month that the specified flows (in cubic meters per second) were observed in the Blue Point cottonwood area below Stewart Mountain Dam. Flows in excess of 283.20 c.m.s. are sufficient to cause some food plain inundation in the Blue Point cottonwoods while flows in excess of $\mathbf{4 2 4 . 7 5}$ c.m.s. cause extensive inundation.

\begin{tabular}{|c|c|c|c|c|c|c|c|c|c|c|c|c|}
\hline \multirow[b]{2}{*}{ Flow } & \multicolumn{12}{|c|}{ Month } \\
\hline & $\mathbf{J}$ & F & $\mathbf{M}$ & A & $\mathbf{M}$ & $\mathrm{J}$ & $\mathbf{J}$ & $\mathbf{A}$ & $\mathbf{S}$ & 0 & $\mathbf{N}$ & D \\
\hline$<5.67$ & 1,165 & 844 & 487 & 235 & 114 & 23 & 17 & 54 & 96 & 421 & 792 & 864 \\
\hline $5.67-28.32$ & 196 & 332 & 499 & 542 & 457 & 225 & 226 & 368 & 347 & 685 & 480 & 445 \\
\hline $28.35-141.58$ & 9 & 91 & 379 & 535 & 794 & 1,102 & 1,152 & 973 & 907 & 288 & 78 & 78 \\
\hline $141.61-283.17$ & 15 & 4 & 22 & 29 & 23 & 0 & 0 & 0 & 0 & 1 & 0 & 1 \\
\hline $283.20-424.75$ & 3 & 0 & 2 & 9 & 7 & 0 & 0 & 0 & 0 & 0 & 0 & 0 \\
\hline$>424.75$ & 7 & 0 & 6 & 0 & 0 & 0 & 0 & 0 & 0 & 0 & 0 & 7 \\
\hline
\end{tabular}

Table 3. Frequency table showing the number of days in each month that the speciffed flows (in cubic feet per second) were predicted for the Blue Point cottonwoods area had no dams been present on the Salt River system. Flows in excess of 283.20 c.m.s. are sufficient to cause some flood plains inundation in the Blue Point cottonwoods while flows in excess of $\mathbf{4 2 4 . 7 5}$ c.m.s. cause extensive inundation.

\begin{tabular}{|c|c|c|c|c|c|c|c|c|c|c|c|c|}
\hline \multirow[b]{2}{*}{ Form } & \multicolumn{12}{|c|}{ Month } \\
\hline & $\mathbf{J}$ & F & $\mathbf{M}$ & $\mathbf{A}$ & $\mathbf{M}$ & $\mathbf{J}$ & $\mathbf{J}$ & $\mathbf{A}$ & $\mathbf{S}$ & 0 & $\mathbf{N}$ & D \\
\hline$<5.67$ & 216 & 92 & 32 & 9 & 184 & 641 & 755 & 231 & 462 & 712 & 528 & 374 \\
\hline $5.67-28.32$ & 881 & 798 & 585 & 564 & 787 & 635 & 619 & 994 & 791 & 617 & 760 & 905 \\
\hline $28.35-141.58$ & 232 & 286 & 643 & 620 & 184 & 34 & 14 & 70 & 47 & 50 & 49 & 75 \\
\hline $141.61-283.17$ & 28 & 60 & 75 & 126 & 206 & 40 & 7 & 92 & 45 & 7 & 8 & 11 \\
\hline $283.20-424.75$ & 12 & 12 & 23 & 27 & 28 & 0 & 0 & 4 & 1 & 3 & 1 & 9 \\
\hline$>424.75$ & 26 & 23 & 37 & 4 & 9 & 0 & 0 & 4 & 4 & 6 & 4 & 21 \\
\hline
\end{tabular}


Bryan, Kirk. 1928. Change in plant associations by change in ground water level. Ecology 9:474-478.

Fahn, A., and E. Werker. 1972. Anatomical mechanisms of seed dispersal. In: T.T. Kozlowski, ed. Seed Biology, Vol. I., Academic Press, New York, N.Y.

Hastings, J.R., and R.M. Turner. 1972. The changing mile, an ecological study of vegetation change with time in the lower mile of an arid and semiarid region. Univ. Arizona Press, Tucson.

Hey, R.D. 1975. Response of alluvial channels to river regulation. p. 183-188. In: Water for Human Needs. Proc. World Congress on Water Resources. 2nd (Vol. 5).

Hudson, Norman. 1971. Soil Conservtion. Cornell University Press, Ithaca N.Y.

Johnson, R.R., and D.A. Jones. 1977. Importance, preservation, and management of riparian habitat. A Symposium. USDA Forest Serv. Gen. Tech. Rep. RM-43. Rocky Mt. Forest and Range Exp. Sta., Fort Collins, Colo.

Johnson, W.C., R.L. Burgess, and W.R. Keammerer. 1976. Forest overstory vegetation and environment on the Missouri River Floodplain in North Dakota. Ecol. Monogr. 46:59-84.

MeNatt, Randy M., Robert J. Hallock, and Arthur W. Anderson. 1980. Riparian habitat and instream flow studies; Lower Verde River, Fort McDowell Reservation, Arizona Riparian Habitat Analysis Group, Office of Environmental Flow, U.S. Forest Service, Region 3, Albuquerque, N.M.
Marion, J.H. 1965. Notes of travel through the territory of Arizona, being an account of the trip made by General George Stoneman and others in the autumn of 1870 . In: D.M. Powell, ed. Univ. Arizona Press, Tucson.

Priest, M.S., and A. Shindala. 1969a. Channel degradation downstream from large dams. Water Power 21:436-437.

Priest, M.S., and A. Shindala. 1969b. Distance downstream from a large dam to the limit of ultimate channel degradation. Proc. of 13 th Internat. Ass. Hydraulic Res. Kyoto, Japan. 5:241-243.

Priest, M.S., and A. Shindala. 1969c. Time required for ultimate channel degradation downstream from large dams. Water Power. 21:472-473.

Thwaites, Reuben G., L.L.D., ed. 1950. The personal narrative of James $O$. Pattie of Kentucky. Arthur H. Clark Co., Cleveland, Ohio.

Turner, R.M., and M.M. Karpisacak. 1980. Recent vegetation changes along the Colorado River between Glen Canyon Dam and Lake Mead, Arizona. U.S. Geol. Survey Prof. Pap. 1132.

U.S. Dep. of Interior. 1934-1979. Geological Survey water supply papers: Surface water supply of the United States. Part 9. Colorado River Basin.

Warren, D.K., and R.N. Turner. 1975. Saltcedar (Tamarix chinensis) seed production, seedling establishment, and response to inundation. J. Ariz. Acad. Sci. 10:135-144.

MOVING? Please try to give us

four weeks notice. Send your

present address label and this

form to Society for Range Management

2760 W. 5th Ave.

Denver, Colo. 80204

\author{
ATTACH OLD \\ ADDRESS LABEL \\ HERE
}

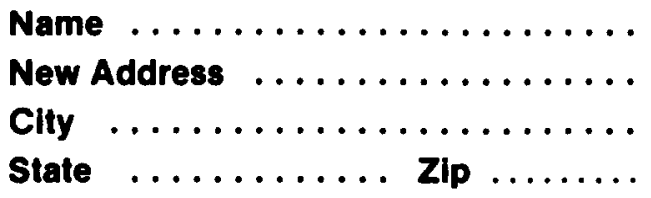

